\title{
Fish Farmers' Perceived Constraints and Suggestions towards the Adoption of Scientific Fish Farming of Pengba (Osteobrama belangeri) in the Valleys of Manipur, India
}

\author{
O.N. Khuman* and Y.J. Singh \\ College of Fisheries, Central Agricultural University (Imphal), Tripura-799 210, India \\ *Corresponding author
}

\section{A B S T R A C T}

Keywords

Constraints,

Suggestion,

Fish Farmers,

Pengba, Manipur

Article Info

Accepted:

18 January 2019

Available Online:

10 February 2019
This study was undertaken at Bishnupur, Imphal West and Thoubal districts of Manipur to identify the constraints and suggestions as perceived by the fish farmers towards the adoption of scientific fish farming of Pengba. Data were obtained through pre tested and structured interview schedule from 80 respondents. Major constraint as perceived by most of the respondents was economic constraints with mean score 1.92. Major perceived suggestions were training programme and group discussion should be held more frequently and timely; fish farmers should be supplied with quality Pengba fish seeds by the concerned government institutions and more information regarding loans or subsidies should be provided to the fish farmers.

\section{Introduction}

Osteobrama belangeri (Val.) is locally known as Pengba in Manipur and Nga-bpe-oung in Myanmar. It has great demand in the state due to its association with the cultural heritage of the state and its unique taste. Pengba is very expensive and is not abundantly available in the market unlike IMCs and other exotic carps. The fish was plentifully found in the Loktak lake of the state which is the largest freshwater lake in the North Eastern India. However, availability of the fish decline from the natural habitat due to prohibition of breeding migration of the fish after the construction of Ithai barrage for supply of water to the Loktak Hydro-Electric Project. (Singh and Devi, 2012).

Factors responsible for the decline of the fish in the state are pollution, habitat degradation due to human activities, construction of dams and introduction of non-native fish species. Induced breeding of Pengba has successfully been achieved with application of pituitary gland extract, Ovaprim, Ovatide and WovaFH in captivity, thereby commercial-scale seed production of Pengba in the state has 
achieved. One of the major problems with Pengba is that it is more susceptible to ulcers and columnaris disease as compared to other carp species at higher stocking densities thereby causing reduction in growth and mass mortalities (Behera et al., 2015). However, least number of fish farmers practise Pengba fish farming in the state. Therefore, this study was purposefully conducted to identify constraints as perceived by the fish farmers towards the adoption of scientific fish farming of Pengba and the suggestion as perceived by the fish farmers towards the adoption of scientific fish farming of Pengba.

\section{Materials and Methods}

The present study was carried out in Bishnupur, Imphal West and Thoubal districts of Manipur. Ten villages were selected with the help of experts, information gathered from a scheme entitled, "Mass Scale Production of State Fish Pengba" which was executed under Rashtriya Krishi Vikas Yojana (RKVY) during $2015-16$ by the Department of Fisheries, Government of Manipur. Primary data were collected from 80 respondents wherein 33 respondents were from the list of beneficiaries provided under the scheme and the remaining 47 respondents were selected with the help of the village key. 22 constraints grouped under six major areas viz., social, economic, promotional, technological, infrastructural and miscellaneous constraints were selected for the study. Statistical analysis such as arithmetic mean and ranking were used for the study.

\section{Results and Discussion}

Constraints as perceived by the fish farmers towards the adoption of scientific fish farming of Pengba

Constraints as perceived by the fish farmers were categorized under different heads viz., social, economic, promotional, technological, infrastructural and others (Table 1). Least concern about Pengba farming due to engagement of fish farmers in other occupations (business/service/agriculture) was the major social constraint with mean score 1.96 followed by far location of pond from home (1.67, II); poaching of fish (1.15, III); poisoning in pond $(1.03, \mathrm{IV})$; and lack of family encouragement $(1.01, \mathrm{~V})$.

Among the economic constraints, substantial mortality of the fish due to diseases was the major constraint as perceived by the respondents with mean score 2.0 followed by high cost on inputs like net, aerator, etc (1.98, II); lack of financial assistance (1.97, III); lack of timely availability of raw material/inputs (1.82, IV); and lack of motivation $(1.81, \mathrm{~V})$.

Lack of training and demonstration programmes on scientific Pengba farming was the major promotional constraint faced by the respondents with mean score 2.0 and this finding is in line with the study conducted by Devi et al., (2014). Lack of support and guidance to avail different information and govt. schemes available was the second major promotional constraint as perceived with mean score 1.97 followed by lack of monitoring mechanism to ensure good quality fish seeds and feeds from retail outlets (1.66, III).

Major technological constraints faced by the respondents were unavailability of required technical assistance on the scientific Pengba farming from a single institutional source in a synchronized manner $(2.0$, I); shortage of skilled extension personnel to demonstrate scientific Pengba farming $(2.0, \mathrm{I})$ is in accordance with the study conducted by Pandey et al., (2014); and complexity in understanding the information provided by experts $(1.69, \mathrm{II})$. 
Table.1 Constrains as perceived by the respondents towards the adoption of scientific fish farming of Pengba $(n=80)$

\begin{tabular}{|c|c|c|c|}
\hline $\begin{array}{l}\text { Sl. } \\
\text { No. }\end{array}$ & Statement & Mean & Rank \\
\hline \multicolumn{4}{|c|}{ A. Social constraints } \\
\hline 1 & Far location of pond from home. & 1.67 & II \\
\hline 2. & Lack of family encouragement. & 1.01 & V \\
\hline 3. & Problems of poaching. & 1.15 & III \\
\hline 4. & Poisoning in pond. & 1.03 & IV \\
\hline 5. & $\begin{array}{l}\text { Being engaged in other occupations } \\
\text { (business/service/agriculture), Pengba farming is least } \\
\text { concentrated. }\end{array}$ & 1.96 & I \\
\hline \multicolumn{4}{|c|}{ B. Economic constraints } \\
\hline 6. & Lack of financial assistance. & 1.97 & III \\
\hline 7. & Substantial fish mortality caused by diseases. & 2 & I \\
\hline 8. & Lack of motivation. & 1.81 & V \\
\hline 9. & High cost on inputs like net, aerator etc. for Pengba culture. & 1.98 & II \\
\hline 10. & Lack of timely availability of raw material/inputs. & 1.82 & IV \\
\hline \multicolumn{4}{|c|}{ C. Promotional constraints } \\
\hline 11. & $\begin{array}{l}\text { Lack of support and guidance on different information and } \\
\text { govt. schemes available. }\end{array}$ & 1.97 & II \\
\hline 12. & $\begin{array}{l}\text { Lack of monitoring mechanism to ensure good quality fish } \\
\text { seeds and feeds from retail outlets. }\end{array}$ & 1.66 & III \\
\hline 13. & $\begin{array}{l}\text { Lack of training and demonstration programmes on } \\
\text { Scientific Pengba farming. }\end{array}$ & 2 & I \\
\hline \multicolumn{4}{|c|}{ D. Technological constraints } \\
\hline 14. & $\begin{array}{l}\text { Dearth of availability of required technical assistance on } \\
\text { Scientific Pengba farming from a single institutional source } \\
\text { in a synchronized manner. }\end{array}$ & 2 & I \\
\hline 15. & Complexity of information provided by experts. & 1.69 & II \\
\hline 16. & $\begin{array}{l}\text { Lack of skilled extension personnel to demonstrate } \\
\text { Scientific Pengba farming. }\end{array}$ & 2 & I \\
\hline \multicolumn{4}{|c|}{ E. Infrastructural constraints } \\
\hline 17. & Lack of transport and marketing facilities. & 1.3 & III \\
\hline 18. & Shortage of manpower. & 1.31 & II \\
\hline 19. & Unavailability of Insurance facilities. & 1.98 & I \\
\hline \multicolumn{4}{|c|}{ F. Miscellaneous constraints } \\
\hline 20. & $\begin{array}{l}\text { Delicate nature of the fish which maximizes the chance of } \\
\text { mortality. }\end{array}$ & 1.56 & II \\
\hline 21. & Poor growth of the fish. & 1.81 & I \\
\hline 22. & Lack of good water source for Pengba farming. & 1.42 & III \\
\hline
\end{tabular}


Table.2 Ranking of major constraints

\begin{tabular}{|l|l|c|c|}
\hline Sl. No. & Constraints & Mean score & Rank \\
\hline 1. & Social constraints & 1.37 & VI \\
\hline 2. & Economic constraints & 1.92 & I \\
\hline 3. & Promotional constraints & 1.87 & III \\
\hline 4. & Technological constraints & 1.89 & II \\
\hline $\mathbf{5 .}$ & Infrastructural constraints & 1.53 & V \\
\hline 6. & Miscellaneous constraints & 1.6 & IV \\
\hline
\end{tabular}

Table.3 Suggestions as perceived by the fish farmers towards the adoption of scientific fish farming of Pengba $(n=80)$

\begin{tabular}{|l|l|l|l|}
\hline S1. No. & \multicolumn{1}{|c|}{ Suggestion } & Mean & Rank \\
\hline 1. & $\begin{array}{l}\text { Need based training programmes and group discussion shoulc } \\
\text { be held more frequently and timely. }\end{array}$ & 1.96 & I \\
\hline 2. & $\begin{array}{l}\text { More information regarding loans or subsidies should be } \\
\text { provided } \\
\text { to the fish farmers. }\end{array}$ & 1.71 & III \\
\hline 3. & $\begin{array}{l}\text { Fish farmers should be supplied with quality Pengba fish } \\
\text { seeds by the concerned government institutions. }\end{array}$ & 1.77 & II \\
\hline 4. & $\begin{array}{l}\text { Regular monitoring of water parameters before, during a } \\
\text { after } \\
\text { fish farming should be done by the experts from the } \\
\text { concerned department. }\end{array}$ & 1.05 & VIII \\
\hline 5. & $\begin{array}{l}\text { Post training evaluation should be conducted to understand } \\
\text { the farmers' problems and to receive their feedback. }\end{array}$ & 1.12 & VI \\
\hline 6. & $\begin{array}{l}\text { More awareness programme on fish disease management, } \\
\text { prevention and cure should be provided to the fish farmers. }\end{array}$ & 1.17 & IV \\
\hline 7. & $\begin{array}{l}\text { More home visit/personal contact with the fish farmers shou } \\
\text { be } \\
\text { made. }\end{array}$ & V \\
\hline 8. & $\begin{array}{l}\text { Good quality fish brooders should be made available by the } \\
\text { concerned department for the fish farmers. }\end{array}$ & 1.07 & VII \\
\hline
\end{tabular}

Major infrastructure constraints faced by the respondents was unavailability of insurance facilities $(1.98$, I) followed by shortage of skilled manpower (1.31, II); and lack of proper transport and marketing facilities (1.30, III).

Apart from the above mentioned constraints, there were miscellaneous constraints as perceived by the fish farmers viz., poor growth of the fish (1.81, I); delicate nature of the fish which maximizes the chance of mortality (1.56, II); and lack of good water source for Pengba farming (1.42, III).

It is evident from Table 2 that economic constraints were noted to be domain of constraint as perceived by most of the fish 
farmers with mean score 1.92. The second constraint as perceived by the fish farmers was technological constraints (1.89) followed by promotional constraints (1.87, III); miscellaneous constraints (1.6, IV); infrastructure constraints $(1.53, \mathrm{~V})$; and social constraints $(1.37, \mathrm{VI})$.

Suggestions as perceived by the fish farmers towards the adoption of scientific fish farming of Pengba

The data in Table 3 showed that most of the respondents suggested to conduct more need based training programme and group discussion frequently and timely (1.96, I). They also suggested that quality Pengba fish seeds should be provided by the concerned organization/institution (1.77, II) and provision of more information regarding loans or subsidies (1.71, III). Other suggestions perceived by the fish farmers were organising more awareness programme on fish disease management, prevention and cure $(1.17, \mathrm{IV})$; establishing personal contact with the fish farmers through more home/farm visit (1.16, $\mathrm{V})$; assessment of post training impact of the fish farmers in order to understand the farmers' problems and to receive their feedback" (1.12, VI); good quality fish brooders should be made available by the concerned department for the fish farmers (1.07, VII); and regular monitoring of water parameters pond before, during and after fish farming should be done by the experts from the concerned department (1.05, VIII).

In conclusion, it is evident from the study that economic constraints was found to be the major constraints as perceived by the fish farmers towards the adoption of scientific fish farming of Pengba. Moreover, majority of the respondents' perceived suggestion were to conduct more need based training programme and group discussion frequently and timely. Many numbers of recommendations can be made for the improvement of Pengba farming. Information with regard to scheme, loan and insurance facilities should be made available to the fish farmers through conduction of group discussion, awareness programme, training programme and use of participatory research tools. As most of the fish farmers count on their own experience for carrying out the Pengba farming, more information related to scientific farming and management practices should be provided with the help of extension personals. Dedicated involvement of the fish farmers in decision-making, planning and dissemination of technology will not only promote production of the fish but also improve the livelihood of the fish farmers and food security.

\section{Acknowledgement}

The authors thankfully acknowledged the support and facilities provided by Dean, College of Fisheries, Lembucherra, CAU(I), Tripura.

\section{References}

Behera, B.K., Meena, D.K., Das, P., Singh, N.S., and Pakrashi, S. 2015. Pengba, a prospective species for diversification of carp polyculture: Conservation and future prospects. World Aquacult. 46(4): $52-54$.

Devi, S.Z., Singh, N.R., Singh,N.A., and Th, L. 2014. Fish Production in Manipur-an Economic Analysis. Journal of Crop and Weed. 10(2): 19-23.

FDM. 2017. Annual Administrative Report 2016 - 2017. Fisheries Department of Manipur. Government of Manipur.

Pandey, D.K., De, H.K., and Hijam, B. 2014. Fish farmers' Perceived Constraints in Transfer of Aquaculture Technology in Bishnupur District of Manipur, India. Int. J. Fish. Aquat. Stud. 2(1): 01-04. 
Singh, K.D., and Devi, W.M. 2012.

Journal of Agriculture and Veterinary Ultrastructure study of egg membrane Science (IOSR-JAVS). 1(4): 49-51.

in Osteobrama belangeri, Val. IOSR

\section{How to cite this article:}

Khuman, O.N. and Singh, Y.J. 2019. Fish Farmers' Perceived Constraints and Suggestions towards the Adoption of Scientific Fish Farming of Pengba (Osteobrama belangeri) in the Valleys of Manipur. Int.J.Curr.Microbiol.App.Sci. 8(02): 2489-2494.

doi: https://doi.org/10.20546/ijcmas.2019.802.289 